\title{
Impact of land cover change on ecosystem service supply in mountain systems: a case study in the Cantabrian Mountains (NW of Spain)
}

\author{
Paula García-Llamas ${ }^{1}$ (D) - Ilse R. Geijzendorffer ${ }^{2,3}$ • Ana P. García-Nieto ${ }^{3,4}$ • Leonor Calvo ${ }^{1}$ • Susana Suárez-Seoane ${ }^{1}$ • \\ Wolfgang Cramer ${ }^{3}$
}

Received: 30 April 2018 / Accepted: 6 September 2018

\begin{abstract}
Land abandonment and the loss of traditional farming practices are thought to control land cover dynamics, and hence the ecosystem service supply in traditionally managed mountain landscapes. We evaluate the impact of land cover changes in Cantabrian Mountains (NW Spain), over 1990-2012, on the potential supply capacity of ecosystem services (regulating, provisioning, and cultural) at both regional and local scales. We also analyze trends in the use of ecosystem services at the local scale. Land cover changes were estimated from CORINE Land Cover database. Patterns of potential ecosystem service supply were assessed by applying an ecosystem service supply capacity matrix and trends in their actual use by using field data. Main trajectories of land cover change encompassed woody vegetation spread in semi-natural open systems and agricultural expansion in the most suitable areas. The capacity of landscape to provide ecosystem services improved during 1990-2012 at both scales. We detected trade-offs between the potential supply of ecosystem services associated to natural systems and those linked to traditional land uses, at both regional and local scales. Changes in the potential supply of ecosystem services matched trends in ecosystem service use. This study could help develop future scenarios to address upcoming challenges in ecosystem service supply.
\end{abstract}

Keywords CORINE land cover · Provision of services · Capacity matrix $\cdot$ Cultural services $\cdot$ Regulation services $\cdot$ Semi-natural landscapes

\section{Introduction}

Mountain systems are key centers of ecological and cultural diversity. They cover $24 \%$ of the Earth's land surface and hold

Electronic supplementary material The online version of this article (https://doi.org/10.1007/s10113-018-1419-2) contains supplementary material, which is available to authorized users.

Paula García-Llamas

pgarc1@unileon.es

Ilse R. Geijzendorffer

geijzendorffer@tourduvalat.org

Ana P. García-Nieto

ana.garcia@imbe.fr

Leonor Calvo

mlcalg@unileon.es

Susana Suárez-Seoane

s.seoane@unileon.es
$12 \%$ of the world's population, providing half of humanity with vital goods and services. They also support $25 \%$ of terrestrial biodiversity, with almost half of the world's biodiversity hot spots (Körner et al. 2005). However, mountains are
Wolfgang Cramer

wolfgang.cramer@imbe.fr

1 Biodiversity and Environmental Management Department., Faculty of Biological and Environmental Sciences, University of León, Campus de Vegazana s/n, 24071 León, Spain

2 Tour du Valat, Research Institute for the Conservation of Mediterranean Wetlands, Sambuc, Arles, France

3 Mediterranean Institute of Marine and Terrestrial Biodiversity and Ecology (IMBE), Aix Marseille University, CNRS, IRD, Avignon University, Aix-en-Provence, France

4 FRACTAL Collective, San Remigio 2, 28022 Madrid, Spain 
highly vulnerable to socioeconomic (Balthazar et al. 2015) and environmental changes (Zlatanov et al. 2017). In European mountains, the landscape has been shaped since historical times through human interventions associated with low intensive agro-silvopastoral activities (Lasanta et al. 2006; Daugstad et al. 2014). Thereby, the combination of traditional farming practices, livestock grazing, and forest management has resulted in highly heterogeneous and spatially structured cultural landscape mosaics (Farina 2000). During the twentieth century, the mountains of southern Europe have experienced a progressive socioeconomic marginalization process associated to rural depopulation, land abandonment, and a decrease in extensive livestock rearing (Conti and Fagarazzi 2005; Gracia et al. 2011). A particularly relevant change has been the decrease in transhumance practices, associated with seasonal movements of flocks of sheep to exploit natural vegetation growth in summer mountain pastures (Vicente-Serrano et al. 2004; Morán-Ordóñez 2012). As a consequence of these factors, the landscape has undergone major transformations leading to the expansion of forests and shrublands in the most marginal areas and the intensification of agricultural practices in the most fertile and accessible lands (Sidiropoulou et al. 2015; Álvarez-Martínez et al. 2016).

Managed mountainous landscapes have traditionally been an important source of ecosystem services (Kozak et al. 2017). In fact, they provide many ecological, sociocultural, and economic benefits for society that include the following: regulating services, such as water cycling regulation or control and mitigation of extreme climatic events; provisioning services, such as grazing, wood-fuel or medicinal plants; and cultural services, zsuch as traditional knowledge or cultural identity (Körner et al. 2005; Foggin 2016). Over time, ecosystem processes that support ecosystem services may be affected by land use changes and the associated land cover changes (Reyers et al. 2009) ultimately impacting on benefits for society and human well-being (Ciftcioglu 2017; Hou et al. 2017; Sonter et al. 2017). Each particular land cover change might lead to a variation in the potential supply (i.e., the hypothetical maximum yield of a service that can be provided by natural components of the ecosystem without the intervention of stakeholders; Geijzendorffer et al. 2015) of multiple ecosystem services (Vallet et al. 2016). However, it is important to consider that the supply of ecosystem services not only can change over time, but also their value and use (i.e., the quantity and type of an ecosystem service which is consumed or utilized by stakeholders; Geijzendorffer et al. 2015) for society. For instance, ecosystem services of high relevance for past traditional lifestyles, such as provisioning services like wool or fuels, have become marginal nowadays; while others less appreciated in the past, such as cultural services including the esthetic aspect or recreation, are increasing in value for current society (Morán-Ordóñez et al. 2013a; de Lima et al. 2016; van der Zanden et al. 2018).
The implications of land cover change for the capacity of mountain systems to provide ecosystem services remains however a controversial issue (Pereira et al. 2005). This controversy lies on the spatiotemporal variability of the effects of land cover changes on ecosystem services and on the existence of trade-offs among different ecosystems services derived from these land cover changes (de Lima et al. 2016; Locatelli et al. 2017). Further, although previous studies (e.g., Tasser et al. 2005; Zlatanov et al. 2017) have assessed the impacts of land cover changes on the supply of particular ecosystem services in European mountains to date, there is limited empirical evidence on the relationship between historical trajectories of land cover change and trajectories of multiple ecosystem services in mountain landscapes (Lavorel et al. 2017). Thereby, enhanced knowledge of the past spatial and temporal patterns of land cover change is required to assess mountain landscape dynamics in relation to multiple ecosystem services (regulation, provisioning, cultural) (Mottet et al. 2006). Information on these temporal and spatial patterns can help land managers develop strategies and policies to improve the inclusion of novel socioecological connections (MacDonald et al. 2000) and ensure the future continuity of benefits to human well-being (Cabel and Oelofse 2012). Box 1 indicates the key concepts used in this study.

The objective of this paper was to analyze the impact of historical land cover changes on the potential supply and use of ecosystem services in mountain landscapes, using the Cantabrian Mountains (NW Spain) as a case study. Specifically, we aimed to (i) detect the main trajectories of land cover change that occurred during the last two decades (1990-2012) considering short time fluctuations (1990-2000, 2000-2006, 2006-2012) and estimate the potential impact on the supply of multiple ecosystem services (regulating, provisioning, and cultural services) at both regional and local scales; (ii) analyze trends in the use of ecosystem services

Box 1 Ecosystem service definitions. Source Geijzendorffer et al. (2015)

Potential supply: the hypothetical maximum quantity of a service that can be provided by natural components of the ecosystem without stakeholders interventions, in a particular area and over a particular time period (eg. density of species in a game reserve)

Actual potential supply: the hypothetical maximum quantity of a service that can be provided by combination of the potential supply and the effect of interventions (e.g., management) by stakeholders, in a particular area and over a particular period of time (density of hunting species in game reserves)

Actual supply: the current amount of an ecosystem services that are provided by the combination of the potential supply and the effect of operations by stakeholders, in a particular are and within a given time period (e.g. number of hunting permits)

Actual use: The quantity and type of an ecosystem service which is consumed or utilized by stakeholders in a particular area and over a particular time period (e.g. number of hunted animal) 
and compare them with potential supply estimates at a local scale, using a subset of ecosystem services. Finally, we provided recommendations for the long-term supply of ecosystem services in traditionally managed mountain landscapes. We hypothesized that land cover changes associated to landscape homogenization would be associated with a loss of capacity of mountain landscapes to supply multiple ecosystem services. Further, we hypothesized that temporal trends in ecosystem service use would be consistent with temporal trends in potential supply.

\section{Study area: definition of two scales of analysis}

The study was conducted in the Cantabrian Mountains (NW Spain) where two spatial scales of analysis were considered: (i) a regional scale, which includes the whole area of the Cantabrian Mountains, covering 31,494 $\mathrm{km}^{2}$; and (ii) a local scale, which includes the Cantabrian Mountains in León province (one of the nine provinces that encompass this mountain system) covering $7151 \mathrm{~km}^{2}$ (23\% of the surface of the Cantabrian Mountains) (Fig. 1).

The Cantabrian Mountains are located at the transition between the Eurosiberian and Mediterranean biogeographic regions (Rivas-Martínez et al. 1987). Annual rainfall varies between 700 and $2200 \mathrm{~mm}$ and mean annual temperature between -2.5 and $15{ }^{\circ} \mathrm{C}$. Altitude ranges from sea level up to 2650 m.a.s.l. In this mountain range, the main land covers are crop fields and grazed meadows along valley bottoms, and heathlands, shrublands, and deciduous forests, dominated by beech (Fagus sylvatica), birch (Betula spp.), and different oak species (Quercus petraea and Q. robur on northern slopes, $Q$. pyrenaica and $Q$. ilex subsp. rotundifolia on southern slopes) in the uplands (Morán-Ordóñez 2012). These woody habitats can spatially intersperse with grazing systems (i.e., open semi-natural habitats mainly comprising pastures,

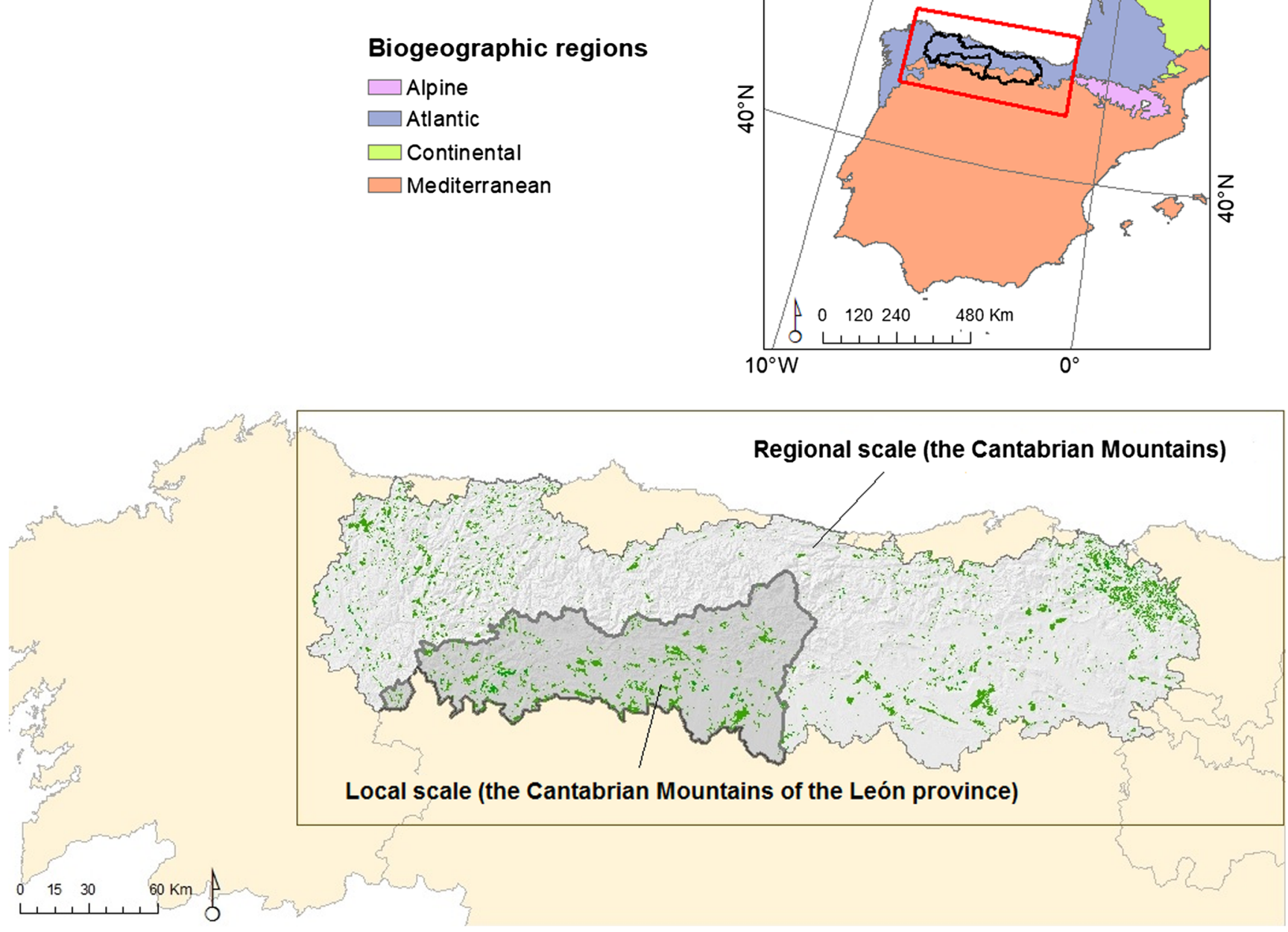

Fig. 1 Location of the study area in NW Spain and analytical scales regional (Cantabrian Mountains) and local (Cantabrian Mountains of León). Information on biogeographic regions was obtained from the Spanish Ministry of Agriculture Food and Environment (http://www. magrama.gob.es/). Spots corresponding to land cover changes during period 1990-2012 are in green, and were obtained from the CORINE Land Cover change layers (http://dataservice.eea.europa.eu) 
grasslands, or open scrublands with very few or no trees) at middle slope levels (Rescia et al. 2008). The tops of the mountains are dominated by rocky formations and natural grasslands. Furthermore, plantations of pines (Pinus pinaster, $P$. radiata) and eucalyptus (Eucalyptus globulus) cover medium-to-low slopes (García-Llamas et al. 2016).

The Cantabrian Mountains of León are located on the southern slope of this mountain system. Annual rainfall ranges from 700 to $1800 \mathrm{~mm}$ and mean annual temperatures are between -2.5 and $12.5^{\circ} \mathrm{C}$. The altitudinal gradient is $391-$ 2650 m.a.s.l. Land cover pattern is similar to that described for the whole Cantabrian Mountains, with croplands and pasturelands along valley bottoms and heathlands and shrublands of Cytisus multiflorus, C. scoparius, Calluna vulgaris, Erica australis, Genista obtusiramea, G. florida subsp. polygaliphylla, G. hispanica subsp. occidentalis, and Vaccinium myrtillus at uplands. Forest formations vary with elevation and appearance. Beech forests dominate at low altitude in northern slopes, with marked xericity and warm temperature, while they also cover southern humid slopes at higher altitudes. Forest dominated by oak species (Q. pyrenaica and Q. ilex subsp. rotundifolia) are common in southern slopes at low altitudes, whereas the highest altitudes are covered by birch groves (Betula celtiberica). The tops of the mountains are dominated by rocky formations and natural grasslands.

The main driving forces historically shaping the landscape across the Cantabrian Mountains have been extensive livestock (sheep, cattle, and horses) grazing, uneven topography, and diverse climatic conditions (Morán-Ordóñez 2012). As a result of interactions among these factors, traditionally managed landscapes, consisting of a mosaic of open habitats, forests, and shrubs, have originated, those being important suppliers of multiple and high valuable cultural, regulating, and provisioning services (Rescia et al. 2010; Morán-Ordoñez et al. 2013a). Within the study area, particularly transhumance sheep activity has played a major role as a driver of landscape change in the León Mountains (MAGRAMA 2013), creating cultural landscapes consisting of an open heath-pasture mosaic (Morán-Ordóñez et al. 2013a). These particular cultural landscapes, associated to the transhumance activity, gave ground to selecting the mountains of León province as our local scale approximation. Nowadays, although livestock rearing (mainly cattle and horses) continues to represent an important economic resource, other activities such as hunting (Morán-Ordóñez 2012), forestry (Delgado-Viñas 2015), or tourism (Álvarez and Pérez 2016) have increased their importance.

The Cantabrian Mountains has suffered notable rural depopulation in the last decades (overall rates of $16 \%$ and $66 \%$ between 1990 and 2012 in the whole Cantabrian Mountains and the Cantabrian Mountains of León province respectively; Online Resource Table A1), with a population of about 1 million and 33,834 inhabitants, respectively, in the
Cantabrian Mountains and the Cantabrian Mountains of Leon in 2011 (http://www.ine.es). Nevertheless, this population is unevenly distributed. In northern provinces, it is concentrated in several main urban centers and relatively close small settlements, with a density of 32 inhabitants $/ \mathrm{km}^{2}$. By contrast, southern provinces have a population density of just 3 inhabitants $/ \mathrm{km}^{2}$ and it is mainly concentrated in small settlements rather isolated from main urban centers. This rural depopulation and the loss of profitability and competitiveness of traditional agro-silvopastoral systems in the last decades have resulted in land abandonment and a loss of traditional management that have undermined landscape patterns and their related multiple bundle of ecosystem services (MoránOrdóñez et al. 2013a).

\section{Methods}

\section{Temporal patterns of land cover change}

We identified land cover changes that have occurred in the Cantabrian Mountains during 1990-2012, at both regional and local scales, on the basis of the change layers available in the CORINE land cover inventory (CLC) (http:// dataservice.eea.europa.eu). This database provides a unique and consistent land cover dataset for Europe, comprising 44 land cover classes grouped in three hierarchical levels, of which 37 are present in our study area (Online Resource Table A2) (Bossard et al. 2000). This database was first available for 1990 and was subsequently updated in 2000, 2006, and 2012. CLC change data reveal changes in land cover with a minimum mapping unit of 5 ha (Nunes de Lima 2005). Despite possible drawbacks to the CLC database, such as the existence of classification errors and uncertainties (García-Llamas et al. 2016), its accessibility and panEuropean comparability and availability at different time spans offer considerable advantages for studying land cover changes (Kroll et al. 2012).

Land cover changes were reported as the net overall change for the whole study period (1990-2012) and also for the three subperiods 1990-2000, 2000-2006, and 2006-2012 (corresponding with the availability of CLC data) to account for short-term temporal fluctuations. Land cover changes were estimated as the variation in the area $(\Delta A)$ occupied by each CLC class for a given time period (Eq. 1) and expressed in per mille, in relation to the study area.

$\Delta A_{i}=\frac{A_{i t 1}-A_{i t 2}}{S A} \times 1000$

Where $A$ is the area in ha of each CLC class $i$, and $t_{1}$ and $t_{2}$ are the years of study, and $S A$ is the overall area of the study region. 
Additionally, we applied transition matrixes of change to identify the main land cover transitions during land cover changes. This is the most conventional method to identify significant transitions between different land covers for a given period (Martínez-Fernández et al. 2015), being widely used in several studies (e.g., Mottet et al. 2006; Morán-Ordóñez 2012; Avalos-Jiménez et al. 2018). In the transition matrix, rows display the classes at an initial time $t_{1}$ and columns display the classes at a final time $t_{2}$. Entries off the diagonal represent the proportion of landscape that undergoes a transition between land cover classes (Martínez-Fernández et al. 2015).

\section{Trends of change in the potential supply of ecosystem services}

The impact of land cover changes on ecosystem service supply was estimated independently at both regional and local scales through a semi-quantitative approach, namely the "ecosystem services capacity matrix method." This method was originally developed by Burkhard et al. (2009) for a German region and further adapted by Stoll et al. (2015) for the whole of Europe. From here on, we will refer to this method as the "Stoll matrix." This matrix provides estimates of the capacity of individual CLC classes (displayed in the X-axis) to supply 31 specific ecosystem services (displayed in the y-matrix) for the whole of Europe (Online Resource Fig. A1). The estimates in the matrix are based on averages of scores assigned by expert knowledge on a scale from " 0 " (no capacity to provide a particular ecosystem service) to "5" (very high capacity to provide a particular ecosystem service). The scoring of supply capacities was collected from 28 expert teams, belonging to the European Long-Term Ecological Research network (LTEREurope), from 11 countries covering a north-south gradient and a west-east gradient in Europe. To this purpose, subsets of the original Stoll matrix including only CLC classes presented at experts' regions were defined, and the original supply scores were updated by the experts based on their knowledge on the ecosystem service provision in the CLC classes at their regions. An updated Stoll matrix was subsequently developed by averaging experts' scores. Only CLC classes that obtained at least three experts' assessments were updated. See Stoll et al. (2015) for further details on definition of the Stoll matrix. Although the method has limitations, such as various degrees of generalization and poor capacity to capture spatial variability (Jacobs et al. 2015), it constitutes a timely and cost-saving tool to evaluate the potential of ecosystems to supply services in changing environments (Balthazar et al. 2015), which has been applied in several studies (Kroll et al. 2012; Nedkov and Burkhard 2012; Sohel et al. 2015). Therefore, using the values of supply capacity of the CLC classes provided in the Stoll matrix, we have estimated the potential supply capacity (PSC) of 31 ecosystem services (i.e., regulating, provisioning, and cultural services) for the 37 CLC classes presented in the study area. PSC values were normalized between 0 and 1 . Subsequently, the variation in the potential supply capacity ( $\triangle \mathrm{PSC}$ ) for each ecosystem service, time period, and analytical scale was computed as follows:

$\Delta \mathrm{PSC} C_{j}=\mathrm{sPSC}_{\mathrm{ji}} \times \Delta A_{i}$

where SPSC is the normalized potential supply capacity value, and $\Delta A$ represents the variation in the area occupied by each land cover at each time period. $j$ corresponds to each ecosystem service and $i$ to each CLC class.

\section{Trends in the use of ecosystem services}

In order to assess temporal trends in the actual use of ecosystem services, we selected a subset of provisioning (timber, wild food, and livestock) and cultural (recreation/tourism) services, due to the lack of available information on actual use for the 31 ecosystem services described in the Stoll matrix. This subset was selected aiming to include services highly valued by traditional society, but also others of increasing value nowadays (Herruzo and Martinez-Jauregui 2013; Morán-Ordóñez et al. 2013a; Schulp et al. 2014; Delgado-Viñas 2015). Indicators of actual use of ecosystem services were defined on the basis of the available data (Table 1) provided by both the regional administration and Rodríguez (2004), for 1990, 2000, 2006, and 2012 (or nearest years). For timber, we used information on wood harvested in public forests. The indicator of wild food was built from hunting data collected in game reserves. Additionally, we also included information on the actual potential supply of this service, which was derived from census of game species (Capreolus capreolus, Cervus elaphus, and Rupicapra rupicapra). For livestock, we used information on the number of cows and transhumant sheep, which were transformed into livestock units (LSU; 1 sheep = $1 \mathrm{LSU}, 1 \mathrm{cow}=5 \mathrm{LSU}$; Olea and Mateo-Tomás 2009). For recreation/tourism, we employed data on visitor flow to natural parks. We also included data on recreation/tourism actual supply (i.e., the current amount of an ecosystem service that is provided by the combination of the potential supply and the effect of operations by stakeholders in a particular area and within a given time period Geijzendorffer et al. 2015) measured as the amount of available rural accommodation.

\section{Results}

\section{Temporal patterns of land cover change}

Land cover dynamics followed similar trends at both regional and local scales. However, changes were particularly pronounced at local scale (Fig. 2). Land cover changes were mainly dominated by an expansion of woody vegetation, 
Table. 1 Indicators of ecosystem service use, actual potential supply, and actual supply at local scale for the Cantabrian Mountains of León

\begin{tabular}{|c|c|c|c|c|}
\hline \multicolumn{2}{|c|}{ Ecosystem service } & \multirow{2}{*}{$\begin{array}{l}\text { Definition } \\
\text { Wood production }\end{array}$} & \multirow{2}{*}{$\begin{array}{l}\text { Indicator } \\
\text { Use: tons of wood/ha of public } \\
\text { utility forests }\end{array}$} & \multirow{2}{*}{$\begin{array}{l}\text { Data source and years } \\
\text { Junta de Castilla y León; years } \\
\text { from } 1992 \text { to } 2012\end{array}$} \\
\hline Provisioning & Timber & & & \\
\hline & Wild food & $\begin{array}{l}\text { Harvest of mushrooms, berries, } \\
\text { animal hunting, and fish catch }\end{array}$ & $\begin{array}{l}\text { Use: number of hunted animals } \\
\text { in game reserves } / 1000 \text { ha } \\
\text { Actual potential supply: density } \\
\text { of hunting species in game } \\
\text { reserves (number of } \\
\text { animals } / 1000 \mathrm{ha} \text { ) }\end{array}$ & $\begin{array}{l}\text { Junta de Castilla y León; years } \\
\text { 2000, } 2006 \text { and } 2012\end{array}$ \\
\hline & Livestock & $\begin{array}{l}\text { Production and utilization of } \\
\text { domestic animals }\end{array}$ & $\begin{array}{l}\text { Use: number of livestock units } \\
\text { per hectare of pastureland }\end{array}$ & $\begin{array}{l}\text { Junta de Castilla y León and } \\
\text { Rodríguez (2004); sheep } \\
\text { years 1990, 2003, and 2012; } \\
\text { cows years } 1990 \text { and } 2012\end{array}$ \\
\hline Cultural & Recreation/tourism & $\begin{array}{l}\text { Recreational activities including } \\
\text { tourism associated with local } \\
\text { environment or landscape }\end{array}$ & $\begin{array}{l}\text { Use: number of tourists visiting } \\
\text { natural parks } \\
\text { Actual supply: amount of rural } \\
\text { accommodation }\end{array}$ & $\begin{array}{l}\text { Junta de Castilla y León; Amount } \\
\text { of rural accommodation: from } \\
2000 \text { to } 2012 \text {; number of tourists } \\
\text { visiting national parks: from } \\
1990 \text { to } 2009\end{array}$ \\
\hline
\end{tabular}

particularly during the subperiod 1990-2000, but with few changes beyond 2000 (Fig. 2a, b). This expansion was primarily associated to a net increase in forests and a loss of open habitats, specifically patches of natural grasslands, moorsheathlands, and sclerophyllous vegetation (Table 2; Online Resource Table A3).

To a lesser extent, the period 1990-2012 was characterized by an expansion and geographic aggregation of agricultural lands in the most suitable areas. This change was associated with a noticeable increase in non-irrigated arable lands at the expense of smallholding agricultural lands (i.e., natural grasslands and areas of complex cultivation patterns). Further, smallholding agriculture also decreased due to land abandonment (mainly of complex cultivation patterns and pasturelands) in marginal areas, and to urban expansion (Fig. 2c, d; Table 2 and Online Resource Table A3). At regional scale, agricultural expansion and aggregation were mainly detected during 1990-2000 and, to a lesser extent, throughout 20062012. Conversely, the decrease in agricultural land was mostly observed over the period 2000-2006 (Fig. 2c). At local scale, the increase in non-irrigated arable lands was constant over time, but agricultural land abandonment peaked between 1990 and 2000 (Fig. 2d).

The expansion of artificial surfaces was a general trend in the whole area of the Cantabrian Mountains throughout all the reporting periods at both scales (Fig. 2, e, f), mainly in forest areas and moors and heathlands (Table 2 and Online Resource Table A3).

\section{Trends of change in the potential supply of ecosystem services}

As a result of the linear relationship between ecosystem service supply and land cover changes, there was a direct correspondence between trends of change in the potential supply of ecosystem services and trends in land cover change previously described. Overall, trends of change in the potential supply of ecosystem services (see Fig. 3) were similar at both scales, albeit changes were relatively larger at local scale and particularly remarkable for the subperiod 1990-2000. Beyond that moment, only slight changes were detected, which suggest stabilization. We found a net increase in the potential supply of all categories of ecosystem services (regulating, provisioning, and cultural) during the whole study period (1990-2012), although some differences should be highlighted. The potential supply of regulating services strongly increased, especially air quality regulation, pest and disease control, erosion regulation, and local climate regulation. Similarly, there was a substantial improvement in the potential supply of provisioning services related to the presence of trees or woodland, such as timber, wood fuel, biochemicals, and wild food. Nevertheless, there was a marked reduction in the potential supply of livestock. At the same time, there were fewer changes in the potential supply of cultural services than regulating or provisioning ones. The greatest increase was estimated for recreation and tourism, landscape esthetics, and natural heritage, showing only a decrease in service knowledge systems, understanding knowledge system as the use of a landscape for environmental knowledge arising from living in this specific environment.

\section{Trends in the use of ecosystem services}

Actual use of the assessed subset of ecosystem services at local scale showed similar temporal patterns to potential supply estimates (see Table 3 and Fig. 3). We found an increasing trend in the tons of timber extracted from public forests from 1990 to 2012, which was analogous to trends in the potential 


\section{Regional scale}

a)

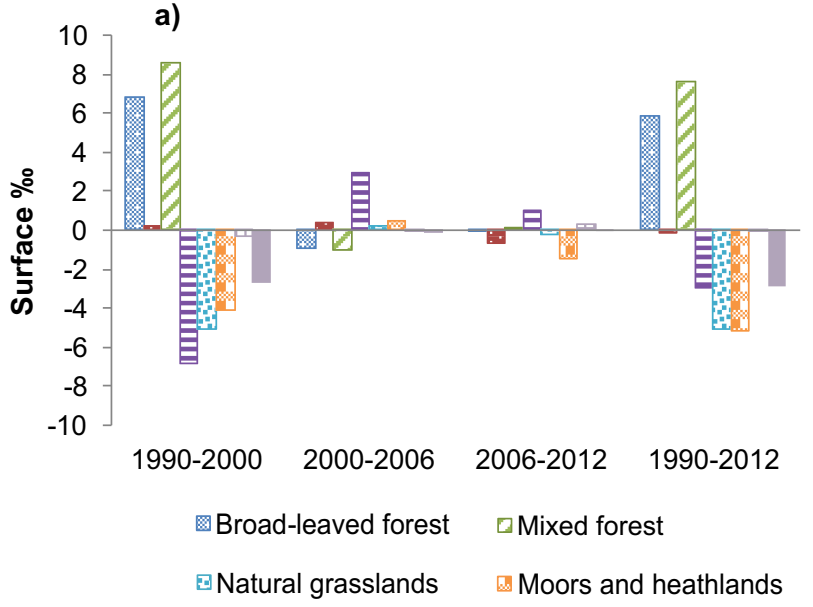

Local scale

Forest systems

b)

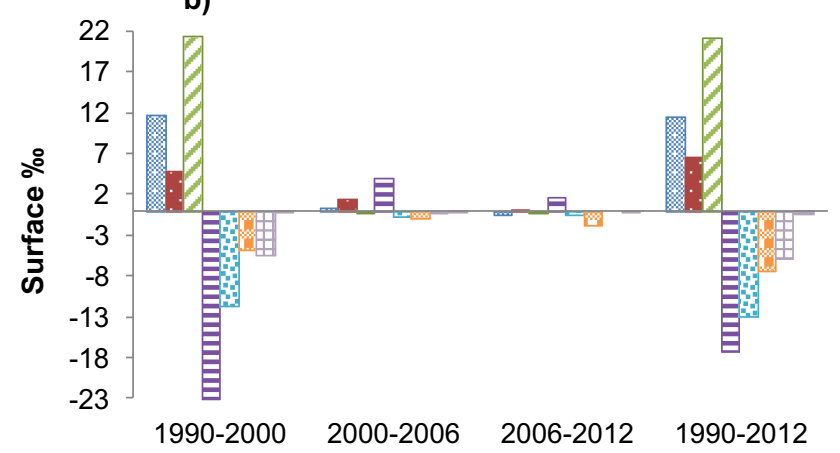

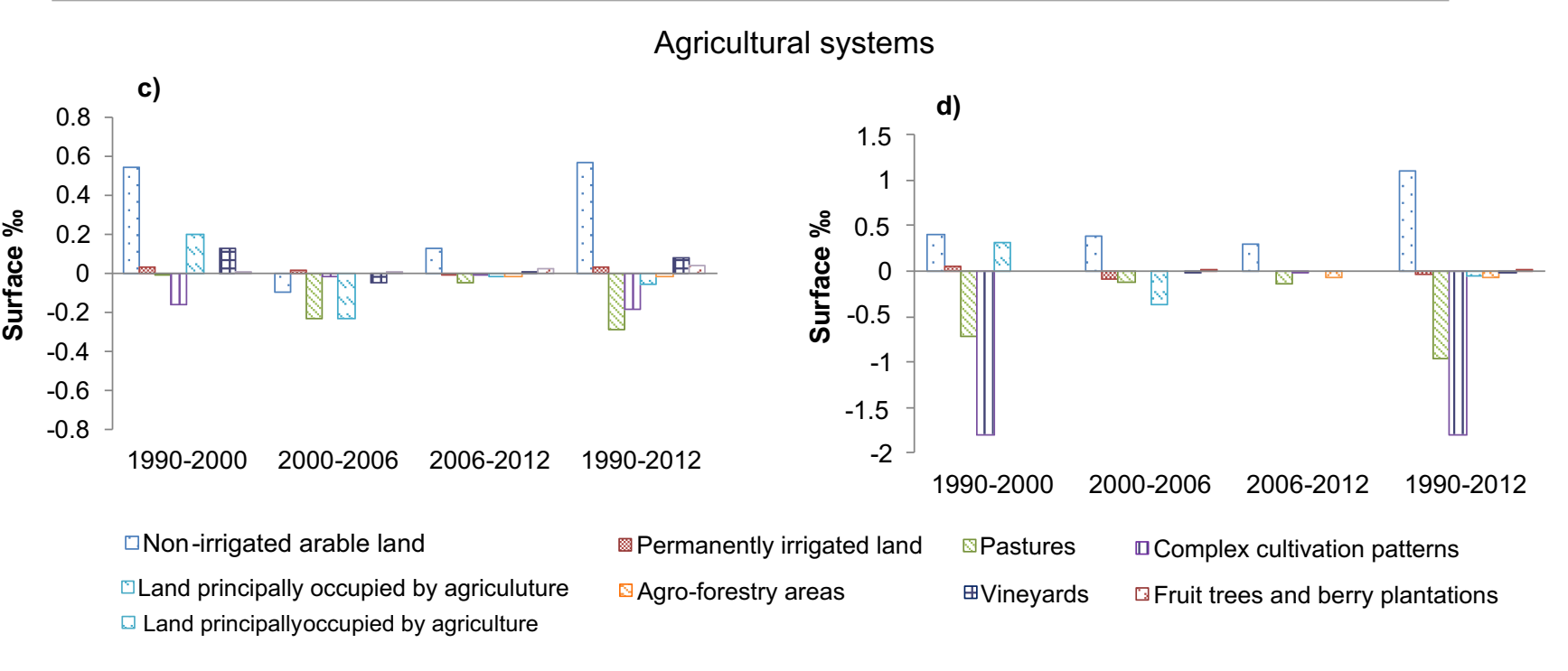

\section{Atificial surfaces}
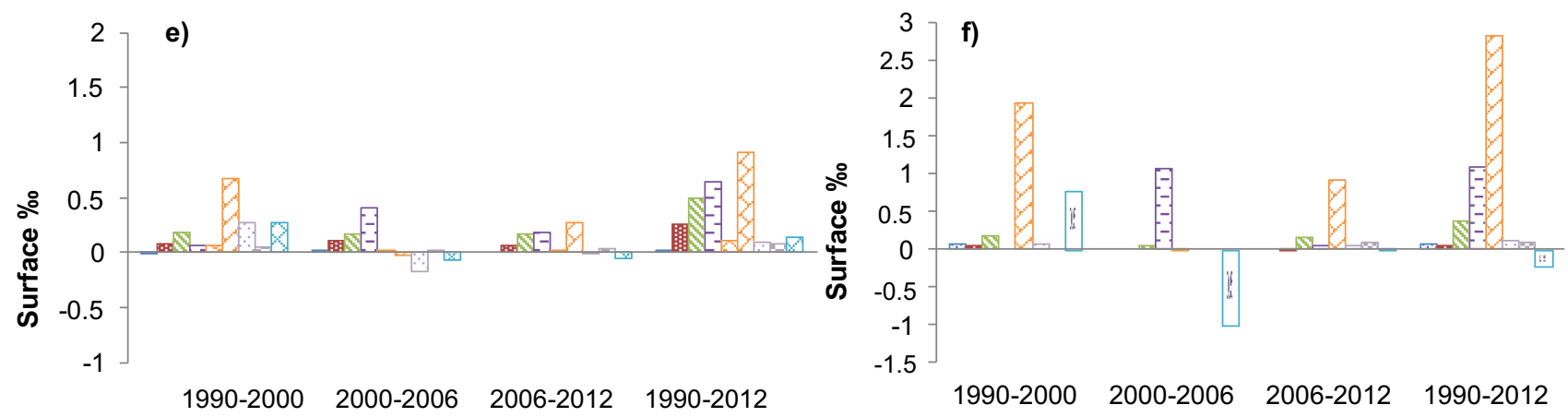

Gontinuous urban fabric $\quad$ Discontinuous urban fabric
Mineral extraction sites $\quad$ Dump sites

\$Industrial or commercial units

$\square$ Sport and leisure facilities $\quad$ Construction sites

Fig. 2 Land cover changes for the overall study period 1990-2012 and the subperiods 1990-2000, 2000-2006, and 2006-2012 at both regional and local scales, representing $\mathbf{a}, \mathbf{b}$ forest systems; $\mathbf{c}, \mathbf{d}$ agricultural

systems; e, f artificial surfaces. Source: CORINE Land Cover database. Charts corresponding to land cover changes at regional and local scales present different scales for a better display 


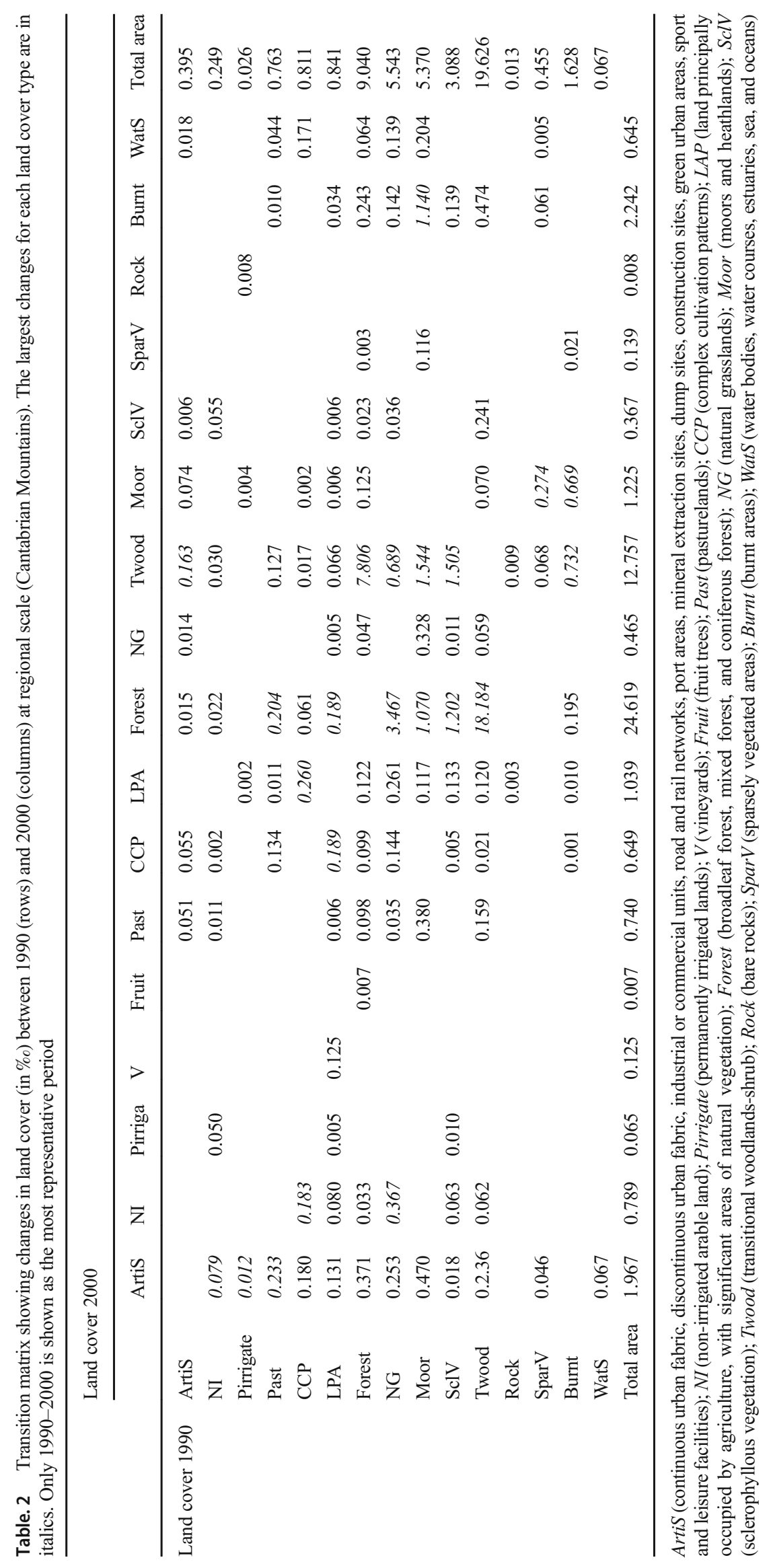



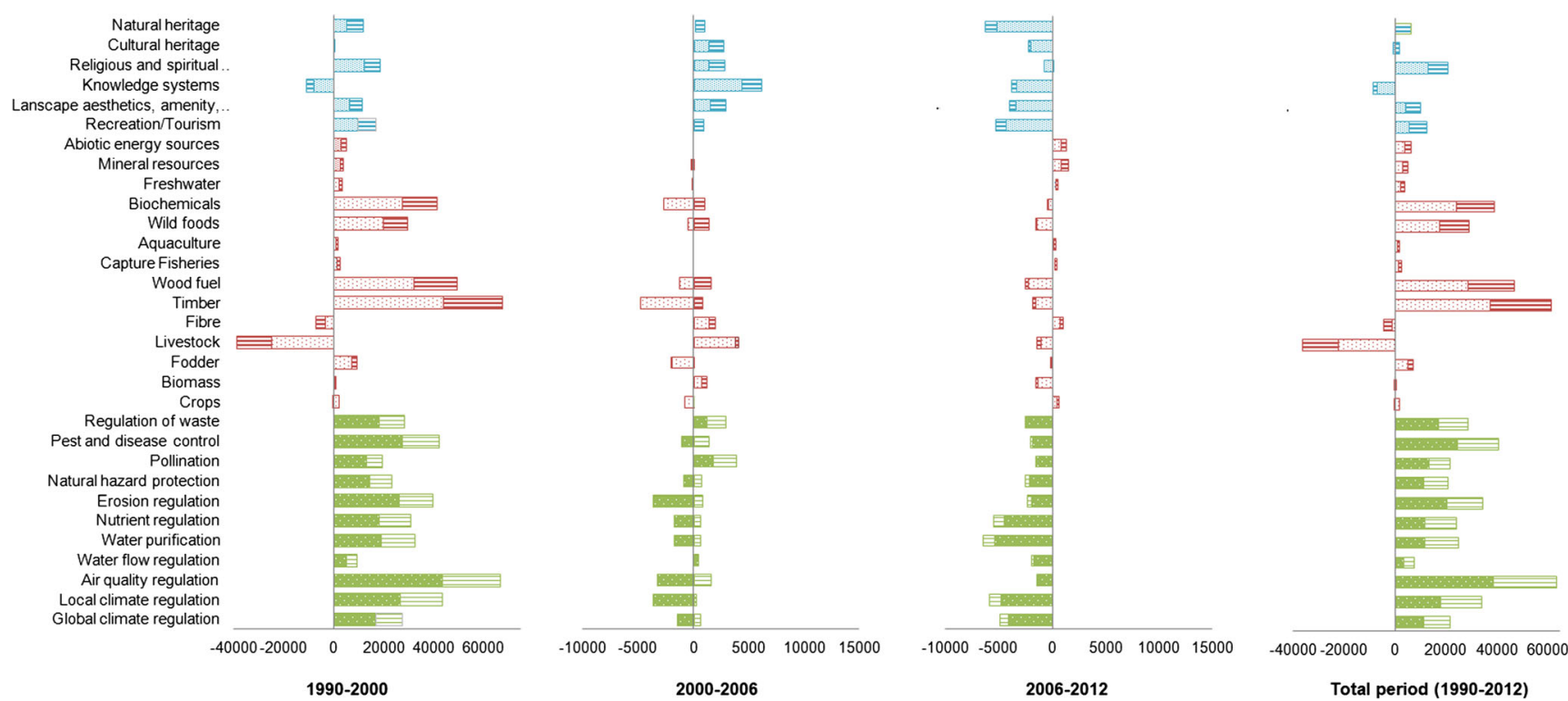

Fig. 3 Changes in the ecosystem service potential supply capacity (cultural, blue; provisioning, pink; and regulating services, green) through subperiods 1990-2000, 2000-2006, and 2006-2012 and all of

supply of timber. The increasing density of game species in hunting reserves between 1990 and 2012 indicated an increase in the actual hunting potential supply, similar to the increasing trends of estimated wild food potential supply. Currently, the number of hunted animals (hunting use) declined from 2000 onwards. Similarly, the number of livestock units decreased over the whole study period, in line with estimates of livestock potential supply. However, analyzing independently the trends of change associated to different livestock species from 1990 to 2012, we did not find a common pattern, as the number of sheep drastically decreased (70\%; from 123,380 to 37,922 sheep), while the number of beef cattle increased (65\%; from 3569 to 9996 heads of cattle) over this time period. Furthermore, the use/supply of recreation and tourism services

Table. 3 Changes in actual use of ecosystem services at local scale, including timber, hunting, livestock, and recreation/tourism, along with changes in potential supply estimates of these services, for the subperiods 1990-2000, 2000-2006, 2006-2012, and for the whole study period

\begin{tabular}{|c|c|c|c|c|}
\hline Ecosystem service & $1990-2000$ & $2000-2006$ & 2006-2012 & $1990-2012$ \\
\hline Timber use (Tn/ha public forest) & 458 & 16 & -59 & 415 \\
\hline Potential timber 1 supply & $23,452.07$ & 817.26 & -287.80 & $23,981.53$ \\
\hline Hunting use (no. of hunted animals/ 1000 ha) & - & -0.1 & -1.27 & -1.37 \\
\hline Potential wild food supply & $10,068.84$ & 1339.66 & -134.96 & $11,270.15$ \\
\hline Actual potential hunting supply (no. of huntable animals/1000 ha) & 44.18 & -18.98 & 10.66 & 35.86 \\
\hline Livestock use (livestock units/ha pastureland) & - & - & - & -1.85 \\
\hline Potential livestock supply & - & - & - & $-14,090.38$ \\
\hline Tourism use (no. of tourists visiting natural parks) & $1,070,000$ & 250,000 & 0 & $1,070,000$ \\
\hline Potential tourism supply & 7387.62 & 799.93 & -287.79 & $23,981.52$ \\
\hline Actual recreation/tourism supply & - & 103 & 93 & 196 \\
\hline
\end{tabular}

1990-2012. Spots refer to the regional scale and stripes the local one. Charts corresponding to changes in ecosystem service supply at regional and local scales present different scales for a better display

showed an important increase between 1990 and 2012. More than 300 new rural tourism establishments were created in 12 years, tripling from 2000 , and the number of visitors to natural parks almost doubled in 20 years. These results were consistent with trends of estimations in tourism/recreation potential supply.

\section{Discussion}

\section{Temporal patterns of land cover change}

The temporal analysis of the land cover changes that have occurred in the Cantabrian Mountains revealed landscape

1990-2012. Information on the actual potential hunting supply and on the actual recreation/tourism supply are also shown. Negative values indicate a decrease 
homogenization at both regional and local scales, which is consistent with the results of other studies carried out across other European mountains (Conti and Fagarazzi 2005; Gracia et al. 2011). We have found two main trends of change: (i) a woody vegetation (shrub and forest) expansion and a loss of open habitats linked to extensification and land abandonment in marginal zones; (ii) to a lesser extent, an expansion and geographic aggregation of agricultural fields in the most suitable areas. These land cover changes have been particularly relevant during the subperiod 1990-2000, which might be attributable to the inclusion of Spain in the European Union market in 1985 and the subsequent implementation of the Common Agricultural Policy (CAP), as identified in other studies (Bernués et al. 2011; Vidal-Legaz et al. 2013). These policies prompted farm specialization and more productive and competitive agricultural systems, at the expense of small farming holdings and traditional practices (Donald et al. 2002; Casas and Manzano 2007). Transformations in farming and agricultural production drove to alterations in the equilibrium between low intensive agricultural lands, grazing and woody systems (Mottet et al. 2006; Rescia et al. 2008), typical of traditionally managed mountain landscapes, and favored secondary succession in different ranges, from grazing areas to transitional stands. Likewise, forest plantation subsidies within the CAP also favored the afforestation of abandoned lands (Rey-Benayas et al. 2007), thus contributing to forest expansion. Notwithstanding, few changes in land cover from 2000 might indicate a new state of equilibrium in the landscape. This reduction in land cover change rates represents a balance between current human and natural forces of change occurring in abandoned or less intensively used land patches (Pelorosso et al. 2011).

In addition to the aforementioned factors, the pronounced trends in land cover change at local scale may be partially related to a historical major role of transhumance in shaping the landscape in this area, in comparison with other areas in the Cantabrian Mountains (MAGRAMA 2013). The socioeconomic crisis greatly affecting transhumance during the twentieth century has caused an increase mainly in beef cattle, requiring less human handling, at the expense of the traditionally migratory sheep flocks (Morán-Ordóñez et al. 2013b). Cattle make a different use of grasslands, being less effective in controlling woody species than sheep (Calvo et al. 2002). At the same time, the traditional transhumance model has been replaced by short movements from nearby lowlands where shepherds spend shorter and shorter periods of time in mountain areas (Olea and Mateo-Tomás 2009). Further, they involve a lower number of animals, thus decreasing pressure on woody systems. Therefore, the important woody vegetation expansion and the loss of open habitats observed during the 1990s at local scale is likely the continuation of trends in land cover change occurring as a result of the decline of the transhumance systems during the twentieth century (Morán-
Ordoñez et al. 2011). This process continued until 2000, when changes tended to stabilized. Additionally, particular socioeconomic factors occurring in the Cantabrian Mountains of León, such as the small size and isolation of villages, loss of facilities, and lack of economic opportunities, have encouraged depopulation. This fact, along with population aging, further explains the abandonment of small holding agriculture and traditional landscape management, inducing pronounced land cover trends at local scale (Morán-Ordóñez 2012).

\section{Impact of land cover changes in ecosystem service supply and trends in ecosystem service use}

According to our results, land cover changes linked to socioeconomic transformations and agricultural policies, mainly occurring during the subperiod 1990-2000, were identified as an important driver of ecosystem service change in traditionally managed landscapes in the Cantabrian Mountains. Our hypothesis that land cover changes associated to landscape homogenization would affect the mountain landscapes' multifunctionality as suppliers of multiple ecosystem services was confirmed. While the potential supply of ecosystem services associated with natural systems increased, that linked to traditional land uses was notably altered, at both regional and local scales, which is in line with other studies carried out in other European mountains, such as the Italian Alps (Conti and Fagarazzi 2005). The consideration of these trade-offs is key to understanding the evolution of traditionally managed landscapes as suppliers of ecosystems services, thus allowing for sustainable policies to be designed. The expansion of woody vegetation positively influenced regulating services in the Cantabrian Mountains, in line with the findings of other studies, including the rise of air quality regulation (Chaparro and Terrasdas 2009), reduction in erosion (Anaya-Romero et al. 2016), improvement in water quality (Navas et al. 2009), and the runoff regulation (Schulz et al. 2010). Additionally, it also benefited the potential supply of timber, wood fuel, wild foods, and biochemicals enhancing the use of some services, such as timber (Maes et al. 2015), consistent with our results at local scale. This further confirms our hypothesis that temporal trends of change in potential supply would meet trends in the use of ecosystem services. At the same time, the increasing density of game species at local scale evidenced how the expansion of woody vegetation, associated to a reduction of livestock pressure, is also likely to favor wildlife species, generally those associated with forested areas (Conti and Fagarazzi 2005). This fact contributes to natural heritage, which might also benefit tourism (Navarro and Pereira 2012). This increase in density of game species was consistent with the increase in potential wild food supply with land cover changes, but it was not corroborated by the hunting use, as opposed to our hypothesis. However, the decline in the number of hunted animals (i.e., hunting use) might not be directly connected with land cover 
changes, but with other factors such as differences in the male to female ratio, pests, weather events, and socioeconomic factors, such as increasing hunting costs and the decrease in hunting tourism. Beyond this, hunting represents an ecosystem service of increasing use at national scale (Herruzo and Martinez-Jauregui 2013), although it might be in conflict with biodiversity conservation (Morán-Ordóñez et al. 2013a), generating opposing interests among stakeholders demanding different ecosystem services. Benefits from the expansion of woody vegetation have been identified as an opportunity for the regeneration of native ecosystems and present rewilding as a potential cost-saving alternative approach to active conservation strategies (Regos et al. 2016).

Notwithstanding, in the Cantabrian Mountains, the importance of preserving traditionally managed landscapes, related to acceptable levels of livestock production and traditional farming practices, as valuable sources of ecosystem services has been stated in previous studies (Rescia et al. 2010; Morán-Ordóñez et al. 2013b). However, the expansion of shrublands and forests into semi-natural grazing systems mainly occurred during 1990-2000 at both local and regional scales, and the decrease in actual use drove a strong impact on the potential supply of livestock, consistent with other studies (OterosRozas et al. 2012). At the same time, these changes in land cover and livestock use might compromise these landscapes and their capacity as suppliers of ecosystem services. In this way, the existence of open habitats and pasture activity has been recognized as crucial in reducing the vulnerability of landscape against natural perturbations, like wildfires, being associated to a reduction in fuel accumulation and its continuity (Zumbrunnen et al. 2012). Additionally, the conservation of high-quality semi-natural grazing systems has benefits for the socioeconomic welfare of mountain villagers derived from the rental of mountain passes (Rodríguez 2004). Further, despite the observed general increase in the potential cultural service supply, mainly associated to woody vegetation expansion, traditionally managed landscapes are important cultural service suppliers. Beyond economic benefits, cultural heritage related to pastoralism and traditional landscape management is a valuable cultural service which may be endangered by the loss of traditional practices (Calvo-Iglesias et al. 2009; Morán-Ordóñez et al. 2013a). Similarly, the mosaic of semi-natural open habitats, forests, and shrubs, jeopardized by the current landscape homogenization trend, is usually perceived as more esthetically attractive (Schirpke et al. 2016) than transitory degraded stages of forest (Pardini et al. 2002). In parallel, traditionally managed landscapes might also contribute to natural heritage. Many flora and fauna species of high conservation value (e.g., Potentilla fruticosa or Luscinia svecica) depend on these habitats and could thus be threatened by their detriment (Levin and Nainggolan 2016; Snell et al. 2017).

The observed enhancement of the potential supply of cultural services from 1990 to 2012, despite the loss of cultural services associated with traditional managed landscapes in the Cantabrian Mountains, might suggest potential limitations of the Stoll matrix to depict local and regional peculiarities in different European regions (Burkhard et al. 2009; Stoll et al. 2015). These limitations may be explained by the challenge of generalizing cultural ecosystem services, whose value is highly site and context dependent (Locatelli et al. 2017; Tolessa et al. 2017). Further, it might highlight an overstatement of the relative role of forest to supply particular services by matrix methods (Maes et al. 2015). In this way, the assessment of cultural services based on methods that attribute values of supply capacity to individual land cover classes might be relatively challenging because each individual might have different value systems based on its experiences, habits, or behavioral traditions (Burkhard et al. 2012; Rodríguez-Loinaz et al. 2015). Limitations of the Stoll matrix would suggest therefore the advisability of using capacity matrixes adapted to different regional socioecological contexts in future studies.

Safeguarding cultural values of traditional managed landscapes offers possibilities for the development of new services of increasing use in the Cantabrian Mountains, such as tourism (Rey-Benayas et al. 2007). Further, the increasing use of tourism could potentially serve as an instrument to diversify the economy and revitalize mountainous rural areas. Such a purpose would require greater engagement of rural society (Cánoves et al. 2004) and a diversified concept of land use planning, which contributes to ecologically sustainably tourism (Höchtl et al. 2005) while maintaining natural and cultural heritage, practices, and landscapes.

In our study area, efforts toward the preservation of traditionally managed landscapes and their character as traditional and cultural ecosystem service suppliers have been put through management and policy actions (e.g., agro-environmental schemes of the CAP) (Rescia et al. 2008). In this context, the degree of restoration of lost ecosystem service values (livestock and cultural services) during 1990-2000 has been scarce, but results beyond 2000 in this study showed trends toward a relatively stable state. At this state, despite the existence of landscape homogenization, maintaining a certain degree of spatial heterogeneity of the landscape mosaic in mountain systems would be beneficial, as it might enhance a more diversified bundle of ecosystem services provided by the different kinds of ecosystems (Lavorel et al. 2017). However, we must note that reported links between land cover and ecosystem service dynamics are temporal and spatial scale dependent (Locatelli et al. 2017). Therefore, even if we found similar trends in land cover and ecosystem services at local and regional scales, these trends might vary across 
other temporal and spatial scales. Additionally, in this study, relationships between land cover changes and ecosystem service supply are assumed to be linear. In this way, we did not consider land use intensity which might shape trajectories of ecosystem service supply and make that the capacity of particular land cover classes to provide ecosystem were not constant over time (Lavorel et al. 2017). Despite these limitations, our study provides valuable contribution to understanding interactions between land cover changes and ecosystem services supplied by mountains landscapes to be used in decisionmaking processes. Thereunder, novel management and policy strategies, aiming at the preservation of traditional landscapes and their ecosystem services, would require adaptation in order to cover current socioecological needs. This can be achieved through the inclusion of socioecological connections and synergies among the primary, secondary, and tertiary sectors (Lago and Sevilla 2008), which enable traditional ecosystem services to be maintained (e.g., livestock), complemented by current new sustainable ones (e.g., tourism).

\section{Conclusions}

Our analysis of land cover dynamics in the Cantabrian Mountains at both regional and local scales revealed a trend toward landscape homogenization and highlighted the importance of considering the temporal scale when analyzing land cover and ecosystem services dynamics. Landscape homogenization affected the multifunctional character of Cantabrian Mountains landscapes. The spread of woodland systems increased the potential supply of regulating and provisioning services in the Cantabrian Mountains. At the same time, the decline in semi-natural open landscapes negatively affected the supply of services linked to traditional uses such as livestock. A poor depiction of the loss of cultural services associated to traditionally managed landscapes suggests the need to revise the Stoll matrix for its correct application in this type of systems. The increasing use of some ecosystem services associated to changes in land cover emphasized the need to integrate both the supply and the future use of all ecosystem services in management plans. The identification of trends in land cover change and ecosystem service supply and use reported in this study could help develop future scenarios to tackle future challenges in ecosystem service supply.

Acknowledgments We are grateful to the FPU mobility program of the Ministry of Education of Spain. We acknowledge support from European Union 7th Framework Programm through the projects EU BON (Contract No. 308454) and OPERAs (Contract No. 308393), as well as the French Laboratory of Excellence OT-Med (A*MIdex project 11IDEX-0001-02). We are also grateful to the Junta de Castilla y León for providing data.

Funding information P. García-Llamas was supported by a predoctoral fellowship from the Ministry of Education of Spain, with reference
FPU12/05194; and by the FPU mobility programme of the Ministry of Education of Spain, with reference EST15/00528, for the financial support during a 3-month research stay at the Mediterranean Institute for Biodiversity and Ecology in Aix-en-Provence, France.

\section{References}

Álvarez J, Pérez C (2016) La dinámica reciente del paisaje del puerto de Leitariegos (montaña occidental asturleonesa) a través de la fotografía aérea. Ería 98(98):241-274. https://doi.org/10.17811/er 98.2015.241-274

Álvarez-Martínez J, Gómez-Villar A, Lasanta T (2016) The use of goats grazing to restore pastures invaded by shrubs and avoid desertification: a preliminary case study in the Spanish Cantabrian Mountains. Land Degrad Dev 27(1):3-13. https://doi.org/10.1002/ldr.2230

Anaya-Romero M, Muñoz-Rojas M, Ibáñez B, Marañón T (2016) Evaluation of forest ecosystem services in Mediterranean areas. A regional case study in South Spain. Ecosyst Serv 20:82-90. https:// doi.org/10.1016/j.ecoser.2016.07.002

Avalos-Jiménez A, Flores-Vilchez F, Nájera-González O, MarceleñoFlores SML (2018) Analysis of the land use and cover changes in the metropolitan area of Tepic-Xalisco (1973-2015) through Landsat images. Sustainability 10:1860. https://doi.org/10.3390/su10061860

Balthazar V, Vanacker V, Molina A, Lambin EF (2015) Impacts of forest cover change on ecosystem services in high Andean mountains. Ecol Indic 48:63-75. https://doi.org/10.1016/j.ecolind.2014.07.043

Bernués A, Ruiz R, Olaizola A, Villalba D, Casasús I (2011) Sustainability of pasture-based livestock farming systems in the European Mediterranean context: synergies and trade-offs. Livest Sci 139(1):44-57. https://doi.org/10.1016/j.livsci.2011.03.018

Bossard M, Feranec J, Otathel J (2000) CORINE land cover technical guide. Addendum 2000. Technical report no 40. European Environment Agency,Copenhagen. http://www.eea.europa.eu/ publications/tech40add

Burkhard B, Kroll F, Müller F, Windhorst W (2009) Landscapes' capacities to provide ecosystem services - a concept for land-cover based assessments. Landsc Online 15(1):1-22. https://doi.org/10.3097/ LO.200915

Burkhard B, Kroll F, Nedkov S, Müller F (2012) Mapping ecosystem service supply, demand and budgets. Ecol Indic 21:17-29. https:// doi.org/10.1016/j.ecolind.2011.06.019

Cabel JF, Oelofse M (2012) An indicator framework for assessing agroecosystem resilience. Ecol Soc 17(1):18. https://doi.org/10. 5751/ES-04666-170118

Calvo L, Tárrega R, De Luis E (2002) The dynamics of Mediterranean shrubs species over 12 years following perturbations. Plant Ecol 160(1):25-42

Calvo-Iglesias MS, Fra-Paleo U, Diaz-Varela RA (2009) Changes in farming system and population as drivers of land cover and landscape dynamics: the case of enclosed and semi-openfield systems in Northern Galicia (Spain). Landsc Urban Plan 90(3):168-177. https://doi.org/10.1016/j.landurbplan.2008.10.025

Cánoves G, Villarino M, Priestley GK, Blanco A (2004) Rural tourism in Spain: an analysis of recent evolution. Geoforum 35(6):755-769. https://doi.org/10.1016/j.geoforum.2004.03.005

Casas R, Manzano P (2007) Valoración económica del pastoralismo en España. https://www.researchgate.net/profile/Pablo_Manzano/ publication/242657902_Valoracion_economica_del_pastoralismo_ en_Espana/links/56092d8108ae-576ce63de-17 e/Valoracioneconomica-del-pastoralismo-en-Espana.pdf

Chaparro L, Terrasdas J (2009) Ecological services of urban forest in Barcelona. Bellaterra, Centre de Recerca Ecologica i Aplicacions Forestals, Universitat Autonoma de Barcelona 
Ciftcioglu GC (2017) Assessment of the relationship between ecosystem services and human wellbeing in the social-ecological landscapes of Lefke region in North Cyprus. Landsc Ecol 32(4):897-913. https:// doi.org/10.1007/s10980-017-0494-y

Conti G, Fagarazzi L (2005) Forest expansion in mountain ecosystems: "environmentalist's dream" or societal nightmare? Planum 11:1-20

Daugstad K, Mier MF, Peña-Chocarro L (2014) Landscapes of transhumance in Norway and Spain: farmers' practices, perceptions, and value orientations. Nor Geogr Tidsskr 68(4):248-258. https://doi. org/10.1080/00291951.2014.927395

Delgado-Viñas C (2015) Agrarian dynamics and landscape in rural mountain areas of Spain. JSSP 4:145-154

Donald PF, Pisano G, Rayment MD, Pain DJ (2002) The Common Agricultural Policy, EU enlargement and the conservation of Europe's farmland birds. Agric Ecosyst Environ 89(3):167-182. https://doi.org/10.1016/S0167-8809(01)00244-4

Farina A (2000) The cultural landscape as a model for the integration of ecology and economics. Biosci Biotechnol Biochem 50(4):313-320

Foggin JM (2016) Conservation issues: mountain ecosystems. Reference Module in Earth Systems and Environmental Science 1-14. doi: https://doi.org/10.1016/B978-0-12-409548-9.09199-5

García-Llamas P, Calvo L, Álvarez-Martínez JM, Suárez-Seoane S (2016) Using remote sensing products to classify landscape. A multi-spatial resolution approach. Int J Appl Earth Obs Geoinf 50: 95-105. https://doi.org/10.1016/j.jag.2016.03.010

Geijzendorffer IR, Martín-López B, Roche PK (2015) Improving the identification of mismatches in ecosystem services assessments. Ecol Indic 52:320-331. https://doi.org/10.1016/j.ecolind.2014.12. 016

Gracia M, Meghelli N, Comas L, Retana J (2011) Land-cover changes in and around a National Park in a mountain landscape in the Pyrenees. Reg Environ Chang 11(2):349-358. https://doi.org/10.1007/ s10113-010-0138-0

Herruzo AC, Martinez-Jauregui M (2013) Trends in hunters, hunting grounds and big game harvest in Spain. Forest Syst 22(1):114 122. https://doi.org/10.5424/fs/2013221-03371

Höchtl F, Lehringer S, Konold W (2005) "Wilderness": what it means when it becomes a reality - a case study from the southwestern Alps. Landsc Urban Planning 70(1):85-95. https://doi.org/10. 1016/j.landurbplan.2003.10.006

Hou Y, Lü Y, Chen W, Fu B (2017) Temporal variation and spatial scale dependency of ecosystem service interactions: a case study on the central Loess Plateau of China. Landsc Ecol 32(6):1201-1217. https://doi.org/10.1007/s10980-017-0497-8

Jacobs S, Burkhard B, Van Daele T, Staes J, Schneiders A (2015) “The matrix reloaded": a review of expert knowledge use for mapping ecosystem services. Ecol Model 295:21-30. doi: https://doi.org/10. 1007/s10980-017-0497-8

Körner C, Ohsawa M, Spehn E, Berge E, Bugmann H, Groombridge B, Hamilton L, Hofer T, Ives J, Jodha N, Messerli B, Pratt J, Price M, Reasoner M, Rodgers A, Thonell J, Yoshino M (2005) Mountain systems. In: Hassan R, Scholes R, Ash N (eds) Ecosystems and human well-being: current state and trends, volume 1. Island Press, Washington DC, pp 683-716

Kozak J, Gimmi U, Houet T, Bollinger J (2017) Current practices and challenges for modelling past and future land use and land cover changes in mountainous regions. Reg Environ Chang 17:21872191. https://doi.org/10.1007/s10113-017-1217-2

Kroll F, Müller F, Haase D, Fohrer N (2012) Rural-urban gradient analysis of ecosystem services supply and demand dynamics. Land Use Policy 29(3):521-535. https://doi.org/10.1016/j.landusepol.2011. 07.008

Lago J, Sevilla L (2008) Análisis DAFO de los Picos de Europa de León. Pecvnia (7):125-148

Lasanta T, González-Hidalgo JC, Vicente-Serrano SM, Sferi E (2006) Using landscape ecology to evaluate an alternative management scenario in abandoned Mediterranean mountain areas. Landsc Urban Plan 78(1):101-114. https://doi.org/10.1016/j.landurbplan. 2005.06 .003

Lavorel S, Grigulis K, Leitinger G, Kohler M, Schirpke U, Tappeiner U (2017) Historical trajectories in land use patterns and grassland ecosystem services in two European alpine landscapes. Reg Environ Chang 17(8):2251-2264. https://doi.org/10.1007/s10113-017$1207-4$

Levin G, Nainggolan D (2016) The significance of spatial fragmentation of land ownership for occurrence of scrubs on semi-natural grasslands. Landsc Ecol 31(9):2031-2044. https://doi.org/10.1007/ s10980-016-0379-5

de Lima GTNP, dos Santos-Hackbart VC, Bertolo LS, dos Santos RF (2016) Identifying driving forces of landscape changes: historical relationships and the availability of ecosystem services in the Atlantic forest. Ecosyst Serv 22:11-17. doi:https://doi.org/10.1016/ j.ecoser.2016.09.009

Locatelli B, Lavorel S, Sloan S, Tappeiner U, Geneletti D (2017) Characteristic trajectories of ecosystem services in mountains. Front Ecol Environ 15(3):150-159. https://doi.org/10.1002/fee. 1470

MacDonald D, Crabtree J, Wiesinger G, Dax T, Stamou N, Fleury P, Gutierrez Lazpita J, Gibon A (2000) Agricultural abandonment in mountain areas of Europe: environmental consequences and policy response. J Environ Manag 59(1):47-69. https://doi.org/10.1006/ jema.1999.0335

Maes J, Fabrega N, Zulian G, Barbosa A, Vizcaino P, Ivits E, Polce C, Vandecasteele I, Rivero IM, Guerra C, Castillo CP, Vallecillo S, Baranzelli C, Barranco R, Batistae Silva F, Jacobs-Crisoni C, Trombetti M, Lavalle C (2015) Mapping and assessment of ecosystems and their services. Trends in ecosystems and ecosystem services in the European Union between 2000 and 2010. European Commission, Luxembourg

MAGRAMA (2013) Libro blanco de la trashumancia en España. Available at http:/www.mapama.gob.es/es/desarrollo-rural/ publicaciones/publicaciones-de-desarrollo-rural/LIBRO BLANCO_2013_tcm7-245950.pdf

Martínez-Fernández J, Ruiz-Benito P, Zavala MA (2015) Recent land cover changes in Spain across biogeographical regions and protection levels: implications for conservation policies. Land Use Policy 44:62-65. https://doi.org/10.1016/j.landusepol.2014.11.021

Morán-Ordóñez A (2012) Spatio-temporal modelling of services provided by the diversity of shrub and heath communities in the Cantabrian Mountains (NW Spain). Effects of socio- economic changes at different scales. Dissertation, University of León

Morán-Ordóñez A, Suárez-Seoane S, Calvo L, de Luis E (2011) Using predictive models as a spatially explicit support tool for managing cultural landscapes. Appl Geogr 31:839-848. https://doi.org/10. 1016/j.apgeog.2010.09.002

Morán-Ordóñez A, Bugter R, Suárez-Seoane S, de Luis E, Calvo L (2013a) Temporal changes in socio-ecological systems and their impact on ecosystem services at different governance scales: a case study of heathlands. Ecosystems 16(5):765-782. https://doi.org/10. 1007/s10021-013-9649-0

Morán-Ordóñez A, Suárez-Seoane S, Marcos E, Luis E, Calvo L (2013b) The heathlands economy in south-west Europe: Cantabrian Mountain (Spain). In: Diemont WE, WJM H, Siepel H, Webb NR (eds) Economy and ecology of heathlands. KNNV Publishing, Zeist, pp 93-104

Mottet A, Ladet S, Coqué N, Gibon A (2006) Agricultural land-use change and its drivers in mountain landscapes: a case study in the Pyrenees. Agric Ecosyst Environ 114(2):296-310. https://doi.org/ 10.1016/j.agee.2005.11.017

Navarro LM, Pereira HM (2012) Rewilding abandoned landscapes in Europe. Ecosystems 15(6):900-912. https://doi.org/10.1007/ s10021-012-9558-7 
Navas A, Valero-Garcés B, Gaspar L, Machín J (2009) Reconstructing the history of sediment accumulation in the Yesa reservoir: an approach for management of mountain reservoirs. Lake Reserv Manage 25(1):15-27. https://doi.org/10.1080/07438140802714304

Nedkov S, Burkhard B (2012) Flood regulating ecosystem servicesmapping supply and demand, in the Entropole municipality, Bulgaria. Ecol Indic 21:67-79. https://doi.org/10.1016/j.ecolind. 2011.06.022

Nunes de Lima MV (2005) Image 2000 and CLC 2000: products and methods. European Commission, Luxembourg

Olea PP, Mateo-Tomás P (2009) The role of traditional farming practices in ecosystem conservation: the case of transhumance and vultures. Biol Conserv 142(8):1844-1853. https://doi.org/10.1016/j.biocon. 2009.03.024

Oteros-Rozas E, González JA, Martín-López B, López CA, Montes C (2012) Ecosystem services and social-ecological resilience in transhumance cultural landscapes: learning from the past, looking for a future. In: Plieninger T, Bieling P (eds) Resilience and the cultural landscape. Cambridge University Press, Cambridge, pp 242-260

Pardini A, Mosquera MR, Rigueiro A (2002) Land management to develop naturalistic tourism. Proceedings of the 5 th international IFSA symposium, Florence, Italy, 8-11 April 2002

Pelorosso R, Della-Chiesa S, Tappeiner U, Leone A, Rocchini D (2011) Stability analysis for defining management strategies in abandoned mountain landscapes of the Mediterranean basin. Landsc Urban Plan 103(3):335-346. https://doi.org/10.1016/j.landurbplan.2011. 08.007

Pereira E, Queiroz C, Pereira HM, Vicente L (2005) Ecosystem services and human well-being: a participatory study in a mountain community in Portugal. Ecol Soc 10(2):14

Regos A, Domínguez J, Gil-Tena A, Brotons L, Ninyerola M, Pons X (2016) Rural abandoned landscapes and bird assemblages: winners and losers in the rewilding of a marginal mountain area (NW Spain). Reg Environ Chang 16(1):199-211. https://doi.org/10.1007/ s10113-014-0740-7

Rescia AJ, Pons A, Lomba I, Esteban C, Dover JW (2008) Reformulating the social-ecological system in a cultural rural mountain landscape in the Picos de Europa region (northern Spain). Landsc Urban Plan 88(1):23-33. https://doi.org/10.1016/j.landurbplan.2008.08.001

Rescia AJ, Willaarts BA, Schmitz MF, Aguilera PA (2010) Changes in land uses and management in two nature reserves in Spain: evaluating the social-ecological resilience of cultural landscapes. Landsc Urban Plan 98(1):26-35. https://doi.org/10.1016/j.landurbplan. 2010.07.007

Rey-Benayas JM, Martins A, Nicolau JM, Schulz JJ (2007) Abandonment of agricultural land: an overview of drivers and consequences. Perspect Agr Vet Sci Nutr Nat Res 2(57):1-14. https:// doi.org/10.1079/PAVSNNR20072057

Reyers B, O'Farrell PJ, Cowling RM, Egoh BN, Le Maitre DC, Vlok JHJ (2009) Ecosystem services, land-cover change, and stakeholders: finding a sustainable foothold for a semiarid biodiversity hotspot. Ecol Soc 14(1):38

Rivas-Martínez S, Bandullo J, Allué J, Montero de Burgos J, González JL (1987) Memoria del mapa de series de vegetación de España. ICONA Serie Técnica, Madrid

Rodríguez M (2004) La trashumancia: cultura, cañadas y viajes. Edilesa, León

Rodríguez-Loinaz G, Alday JG, Onaindia M (2015) Multiple ecosystem services landscape index: a tool for multifunctional landscapes conservation. J Inviron Manage 147:152-163. https://doi.org/10.1016/j. jenvman.2014.09.001

Schirpke U, Timmermann F, Tappeiner U, Tasser E (2016) Cultural ecosystem services of mountain regions: modelling the aesthetic value. Ecol Indic 69:78-90. https://doi.org/10.1016/j.ecolind.2016.04.001
Schulp CJE, Thuiller W, Verburg PH (2014) Wild food in Europe: a synthesis of knowledge and data of terrestrial wild food as an ecosystem service. Ecol Econ 105:292-305. https://doi.org/10.1016/j. ecolecon.2014.06.018

Schulz JJ, Cayuela L, Echeverría C, Salas J, Benayas JMR (2010) Monitoring land cover change of the dryland forest landscape of Central Chile (1975-2008). Appl Geogr 30:436-447

Sidiropoulou A, Karatassiou M, Galidaki G, Sklavou P (2015) Landscape pattern changes in response to transhumance abandonment on Mountain Vermio (North Greece). Sustainability 7(11):1565215673. https://doi.org/10.1016/j.apgeog.2009.12.003

Snell RS, Peringer A, Bugmann H (2017) Integrating models across temporal and spatial scales to simulate landscape patterns and dynamics in mountain pasture-woodlands. Landsc Ecol 32(5):10791096. https://doi.org/10.1007/s10980-017-0511-1

Sohel SI, Mukul SA, Burkhard B (2015) Ladscape's capacities to supply ecosystem services in Bangladesh: a mapping assessment for Lawachara National Park. Ecosyst Serv 12:128-135. https://doi. org/10.1016/j.ecoser.2014.11.015

Sonter LJ, Johnson JA, Nicholson CC, Richardson LL, Watson KB, Ricketts TH (2017) Multi-site interactions: understanding the offsite impacts of land use change on the use and supply of ecosystem services. Ecosyst Serv 23:158-164. https://doi.org/10.1016/j. ecoser.2016.12.012

Stoll S, Frenzel M, Burkhard B, Adamescu M, Augustaitis A, Baeßler C, Bonet FJ, Carranza ML, Cazacu C, Cosor GL, Díaz-Delgado R, Grandin U, Haase P, Hämäläinen H, Loke R, Müller J, Stanisci A, Staszewski T, Müller F (2015) Assessment of ecosystem integrity and service gradients across Europe using the LTER Europe network. Ecol Model 295:75-87. https://doi.org/10.1016/j.ecolmodel. 2014.06.019

Tasser E, Tappeiner U, Cernusca A (2005) Ecological effects of land-use changes in the European Alps. In: Huber UM, Bugmann HKM, Reasoner MA (eds) Global change and mountain regions - a state of knowledge overview. Springer, Dordrecht, pp 413-425

Tolessa T, Senbeta F, Kidane M (2017) The impact of land use/land cover change on ecosystem services in the central highlands of Ethiopia. Ecosyst Serv 23:47-54. https://doi.org/10.1016/j.ecoser.2016.11. 010

Vallet A, Locatelli B, Levrel H, Pérez CB, Imbach P, Carmona NE, Manlay R, Oszwald J (2016) Dynamics of ecosystem services during forest transitions in Reventazón, Costa Rica. PLoS One 11(7): e0158615. https://doi.org/10.1371/journal.pone.0158615

Vicente-Serrano SM, Lasanta T, Romo A (2004) Analysis of spatial and temporal evolution of vegetation cover in the Spanish Central Pyrenees: role of human management. Environ Manag 34(6):802818. https://doi.org/10.1007/s00267-003-0022-5

Vidal-Legaz B, Martínez-Fernández J, Picón AS, Pugnaire FI (2013) Trade-offs between maintenance of ecosystem services and socioeconomic development in rural mountainous communities in southern Spain: a dynamic simulation approach. J Environ Manag 131: 280-297. https://doi.org/10.1016/j.jenvman.2013.09.036

van del Zanden EH, Carvalho-Ribeiro SM, Verburg PH (2018) Abandonment landscapes: user attitudes, alternative futures and land management in Castro Laboreiro, Portugal. Reg Environ Change Published Online doi:https://doi.org/10.1007/s10113-018-1294-x, $18,1509,1520$

Zlatanov T, Elkin C, Irauschek F, Lexer MJ (2017) Impact of climate change on vulnerability of forests and ecosystem service supply in Western Rhodopes Mountains. Reg Environ Chang 17:79-91. https://doi.org/10.1007/s10113-015-0869-Z

Zumbrunnen T, Menéndez P, Bugmann H, Conedera M, Gimmi U, Bürgi M (2012) Human impacts on fire occurrence: a case study of hundred years of forest fires in a dry alpine valley in Switzerland. Reg Environ Chang 12(4):935-949. https://doi.org/10.1007/s10113-012-0307-4 